OPEN ACCESS

Edited by:

Linxin Li,

University of Oxford, United Kingdom

Reviewed by:

Prasad V. Katakam,

Tulane University, United States

Yannick Béjot

Centre Hospitalier Regional

Universitaire De Dijon, France

*Correspondence:

Sylvain Doré

sdore@ufl.edu

Specialty section:

This article was submitted to Stroke,

a section of the journal

Frontiers in Neurology

Received: 21 October 2019 Accepted: 16 April 2020

Published: 10 June 2020

Citation:

Yarlagadda K, Ma N and Doré S (2020) Vitamin D and Stroke: Effects on Incidence, Severity, and Outcome and the Potential Benefits of

Supplementation.

Front. Neurol. 11:384.

doi: 10.3389/fneur.2020.00384

\section{Vitamin D and Stroke: Effects on Incidence, Severity, and Outcome and the Potential Benefits of Supplementation}

\author{
Keerthi Yarlagadda ${ }^{1}$, Nicholas $\mathrm{Ma}^{1}$ and Sylvain Doré ${ }^{1,2 *}$ \\ ${ }^{1}$ Doré Lab, Department of Anesthesiology, Center for Translational Research in Neurodegenerative Disease, McKnight Brain \\ Institute, University of Florida College of Medicine, Gainesville, FL, United States, ${ }^{2}$ Doré Lab, Departments of Neurology, \\ Psychiatry, Pharmaceutics, Psychology, and Neuroscience, McKnight Brain Institute, University of Florida College of \\ Medicine, Gainesville, FL, United States
}

Vitamin D serum level has been positively associated with improved cardiovascular health, especially with reduction of stroke risk. This systemic review summarizes and synthesizes findings from studies relevant to the relationship between vitamin $\mathrm{D}$ and stroke risk, severity, and outcome; potential mechanisms explaining such a relationship; and outcomes from vitamin D supplementation. The literature shows that vitamin $D$ deficiency is a significant risk factor for ischemic stroke, with sun exposure, sex, age, race, diabetes, and genetics playing a role as well. Stroke severity and short- and long-term outcomes also worsen with vitamin D deficiency. The neuroprotective mechanisms by which vitamin D operates to mitigate stroke onset and outcomes have yet to be fully studied, but researchers have proposed several pathways, including promotion of certain neuroprotective growth factors, reduction of arterial pressure through vasodilation, and inhibition of reactive oxygen species. There is some evidence that vitamin D supplementation could lower stroke risk and improve recovery, though outcomes can also be negligible or negative. Although results are mixed and the limitations of vitamin D supplementation merit some caution, vitamin D overall plays a significant role in stroke health. Future research should further develop understanding of the neuroprotective mechanisms of vitamin $D$ and study how supplementation could be administered effectively in stroke treatment.

Keywords: vitamin D, ischemic stroke, risk, outcome, supplementation

\section{INTRODUCTION}

Stroke is the second leading cause of death worldwide, accounting for over $10 \%$ or 5.7 million deaths annually, with the total number of cases predicted to rise over the next few decades (1). Although stroke mortality has declined to 40-60\% in the United States and other developed countries because of strict blood pressure control, the burden of stroke is still rising due to an increase in the older population $(1,2)$. Likewise, increased longevity in developing nations has led to rising stroke prevalence in middle-income countries $(1,2)$.

Vitamin D (VD) is an organic compound consisting of fat-soluble ecosteroids mainly responsible for regulation of calcium and phosphorous levels, among other physiological functions $(3,4)$. Calcitriol $[1,25(\mathrm{OH}) 2 \mathrm{D} 3]$ is the active form of $\mathrm{VD}$ that binds to the VD receptor 
(VDR), dimerizes with retinoid $\mathrm{X}$ receptor (RXR), and translocates to the nucleus to bind to $\mathrm{VD}$ response elements (VDRE) (5). VD is measured by levels of a metabolically inactive precursor, 25-hydroxyvitamin $\mathrm{D}_{3}$ hydroxy $\mathrm{VD}$ [25(OH) $\mathrm{D}_{3} \mathrm{D} 3$ ], since the serum concentration of $1,25(\mathrm{OH})_{2} \mathrm{D}_{3}(\leq 100 \mathrm{pM})$ is significantly lower than $25(\mathrm{OH}) \mathrm{D}_{3} \mathrm{D} 3(\leq 100 \mathrm{nM})$ (6). Optimal $25(\mathrm{OH}) \mathrm{D}_{3}$ levels are at least $30 \mathrm{ng} / \mathrm{ml}(75 \mathrm{nmol} / \mathrm{L}) 25(\mathrm{OH}) \mathrm{D}_{3}(3)$, with levels below $12 \mathrm{ng} / \mathrm{mL}$ ( $30 \mathrm{nmol} / \mathrm{L})$ considered deficient by the Institute of Medicine (7). 25(OH) $\mathrm{D}_{3}$ deficiency can cause bone demineralization and is associated with obesity, diabetes, hypertension, and cancer $(3,4,8) .25(\mathrm{OH}) \mathrm{D}_{3}$ levels have been associated with regulating cardiac myocyte, systolic blood pressures, glycemic control, vascular function, high-density cholesterol, and metabolic syndrome, which all influence cerebrovascular and cardiovascular events $(3,4,8-$ 15). $25(\mathrm{OH}) \mathrm{D}_{3}$-deficient patients are recommended to orally consume at least 50,000 IU (1,250 mcg) of ergocalciferol, or VD2, once per week or more for 6-8 weeks, followed by $800-1,000 \mathrm{IU}$ (20-25 mcg) daily (16).

Researchers are increasingly focusing more on the relationship between $\mathrm{VD}$ and stroke. Literature reviews have identified $25(\mathrm{OH}) \mathrm{D}_{3}$ deficiency as an independent risk factor for stroke, highlighting the potential for using supplementation as a treatment for stroke (17-19). This review paper seeks to update the literature on VD's association with stroke while also highlighting the promises and limitations of supplementation in stroke treatment and prevention.

\section{VASCULAR OUTCOMES FROM EXPERIMENTAL DATA}

Although $1,25(\mathrm{OH})_{2} \mathrm{D}_{3}$ 's mechanism against ischemic stroke has yet to be fully understood, several neuroprotective mechanisms have been proposed $(20-24) \cdot 1,25(\mathrm{OH})_{2} \mathrm{D}_{3}$ can promote the expression of insulin-like growth factor 1 (IGF-1), which has neuroprotective capabilities that help combat axon and dendrite degeneration $(20,23)$, as well as antithrombotic capabilities through activation of plasminogen $(20,21)$. In light of this mechanism, diabetes may serve more as a causal link between VD and stroke than as a confounding variable, as suggested in recent findings $(12,25)$.

$1,25(\mathrm{OH})_{2} \mathrm{D}_{3}$ could also induce vasodilation, relieve arterial pressure, and improve post stroke blood flow to neurons by potentiation of nitric oxide synthase (NOS) $(20,23)$. These benefits can especially be seen in $1,25(\mathrm{OH})_{2} \mathrm{D}_{3}$ 's antiinflammatory effects and attenuation of cerebral vasospasm in hemorrhagic stroke development, as measured by vessel diameter and endothelial function of the basilar artery (26). Anti-inflammation of myeloid and endothelial cells is believed

\footnotetext{
Abbreviations: BBB, blood brain barrier; DBP, VD binding protein; HR, hazard ratio; IGF-1, Insulin-like growth factor 1; mRS, Modified rankin scale; NOS, nitric oxide synthase; RXR, retinoid X receptor; SDF1 $\alpha$, Stromal cell-derived factor $1 \alpha$; SNP, Single nucleotide polymorphism (SNP); VEGF, vascular endothelial growth factor; Vitamin D, VD; VDD, Vitamin D deficiency; VDRE, VD response elements.
}

to be the result of $1,25(\mathrm{OH})_{2} \mathrm{D}_{3}$ induction of stromal cellderived factor $1 \alpha(\mathrm{SDF} 1 \alpha)$, vascular endothelial growth factor (VEGF), and endothelial NOS (26). In mice, VD inhibits reninangiotensin, a vasoconstrictor, and thus can help reduce blood pressure and hinder the onset of cardiovascular diseases (22). Therefore, lower $25(\mathrm{OH}) \mathrm{D}_{3}$ levels may lead to vascular stiffness, supported by evidence of higher abnormalities in right and left brachioarterial pulse wave velocities (PWV) and carotid-femoral PWV among 25(OH) $\mathrm{D}_{3}$-deficient and -insufficient patients with coronary artery disease (27). Narrower and stiffer vessels due to $25(\mathrm{OH}) \mathrm{D}_{3}$ deficiency could therefore increase the risk of occlusion; indeed, low $25(\mathrm{OH}) \mathrm{D}_{3}$ levels in patients with ischemic stroke have been strongly linked to deep venous thrombosis development (28). 1,25( $\mathrm{OH})_{2} \mathrm{D}_{3}$, as an antioxidant, also inhibits reactive oxygen species production to prevent blood brain barrier (BBB) dysfunction in cerebral endothelial cells after an ischemic stroke in a mouse stroke model (24). In a male rat model, deficiency in $25(\mathrm{OH}) \mathrm{D}_{3}$ has been found to significantly decrease expression of tight-junction proteins occludin and claudin-5 after ischemic stroke, therefore leading to greater $\mathrm{BBB}$ dysfunction (29). $25(\mathrm{OH}) \mathrm{D}_{3}$ deficiency will not only reduce neuroprotection, but also cause conditions linked to cardiovascular disease. For instance, hyperparathyroidism, triggered by $25(\mathrm{OH}) \mathrm{D}_{3}$ deficiency to counteract low serum calcium, has been linked to inflammation and cardiac hypertrophy (21). Furthermore, lower $25(\mathrm{OH}) \mathrm{D}_{3}$ levels in patients with stroke is associated with more severe white matter lesions, enlarged perivascular spaces, and MRI-detected cerebral small-vessel disease burden (30).

\section{FUNCTIONAL OUTCOMES FROM OBSERVATIONAL STUDIES}

$25(\mathrm{OH}) \mathrm{D}_{3}$ deficiency has been linked to greater stroke severity and negative post stroke outcomes (20-22, 31-35). Lower serum $25(\mathrm{OH}) \mathrm{D}_{3}$ levels in patients with stroke are independently associated with higher infarct volumes, although causality has yet to be determined $(20-22,36)$. Overall stroke severity, assessed using the National Institutes of Health Stroke Scale, was worse in $25(\mathrm{OH}) \mathrm{D}_{3}$-deficient patients with stroke, whereas patients with sufficient to optimal VD levels had lower scores on that scale, or less severe strokes, on average $(20-22,31,32,37)$. Short-term post stroke outcome, measured by the modified Rankin Scale (mRS) at patient discharge, was similarly poorer among $25(\mathrm{OH}) \mathrm{D}_{3}$-deficient patients with stroke (20, 31-34, 36). 25(OH) $\mathrm{D}_{3}$-deficient patients also had higher mRS scores 3 months post stroke, reflecting relatively worse longer-term outcomes (20,31, 32, 34, 37). A significant nonlinear relationship between $25(\mathrm{OH}) \mathrm{D}_{3}$ and Barthel Index scores has also been found at 3 months, with the strongest association up to $16 \mathrm{ng} / \mathrm{ml}$ $25(\mathrm{OH}) \mathrm{D}_{3}$ before the effects of higher $25(\mathrm{OH}) \mathrm{D}_{3}$ diminish (38). Likewise, cognitive impairment at 1 month after ischemic stroke, assessed by the Mini-Mental State Examination and adjusted for risk factors, was also significantly higher among $25(\mathrm{OH}) \mathrm{D}_{3}$ deficiency patients, although not significantly different between $25(\mathrm{OH}) \mathrm{D}_{3}$-sufficient and -insufficient patients (39). Regarding longer-term outcomes, only one study with a small sample of 
50 patients, found no significant correlation between $\mathrm{mRS}$ scores and $25(\mathrm{OH}) \mathrm{D}_{3}$ after 6 months (35).

Lower $25(\mathrm{OH}) \mathrm{D}_{3}$ in patients with ischemic stroke has also been correlated with poorer scores for other metrics assessing mental and physical post stroke outcome. Such metrics include the Functional Independence Measurements of Motor and Cognitive Function, Functional Ambulatory Scale, and the Mini-Mental State Examination; however, there was no such correlation for haemorrhagic stroke (23). Overall cardiovascular disease mortality has been correlated with lower $25(\mathrm{OH}) \mathrm{D}_{3}$ levels (22). There is an inverse relationship between $25(\mathrm{OH}) \mathrm{D}_{3}$ levels and 1-year mortality for ischemic stroke patients younger than age 75, after adjusting for other risk factors, although the association between death and $25(\mathrm{OH}) \mathrm{D}_{3}$ deficiency was no longer observed for patients older than 75 years (40). Ischemic stroke recurrence within at least 3 months has also been found to be negatively correlated with serum $25(\mathrm{OH}) \mathrm{D}_{3}$ levels $(21)$. The negative association between $25(\mathrm{OH}) \mathrm{D}_{3}$ levels and stroke recurrence, as well as mortality, continues for at least up to 24 months (41). Prospective population health studies observing dietary intake have also noted that dietary intake of VD in middle-aged to senior populations was associated with reduced risk of stroke incidence and mortality $(42,43)$. The negative association between $25(\mathrm{OH}) \mathrm{D}_{3}$ levels and stroke recurrence, as well as mortality, continues for at least up to 24 months (41).

VD deficiency (VDD), with serum levels lower than $20 \mathrm{ng} / \mathrm{ml}$ $(50 \mathrm{nmol} / \mathrm{L}) 25(\mathrm{OH}) \mathrm{D}_{3}$, can cause bone demineralization and is associated with obesity, diabetes, hypertension, and cancer $(3,4,8)$. VD levels have been associated with regulating cardiac myocyte, systolic blood pressures, glycemic control, vascular function, high-density cholesterol, and metabolic syndrome, which all influence cerebrovascular and cardiovascular events (3, $4,8-15,44)$. VDD patients are recommended to orally consume at least 50,000 IU (1,250 mcg) of VD once per week or more for 6-8 weeks, followed by $800-1,000$ IU (20-25 mcg) daily.

Researchers are increasingly focusing more on the relationship between VD and stroke. Literature reviews have identified VDD as an independent risk factor for stroke, highlighting the potential for using supplementation as a treatment for stroke (17-19). This review paper seeks to update the literature on VD's association with stroke while also highlighting the promises and limitations of supplementation in stroke treatment and prevention.

\section{VARIABLES EXPLORED IN OBSERVATIONAL STUDIES BEHIND CORRELATION BETWEEN VD AND STROKE}

\section{Sun Exposure}

VDVD synthesis requires adequate sunlight exposure, little of which is attained in regions above and below $33^{\circ}$ latitude during the winter, and only occurring at peak zenith angles of the sun (45). Nevertheless, a meta-analysis indicates no significant correlation on a global scale (46). There are other variables to consider when explaining $25(\mathrm{OH}) \mathrm{D}_{3}$ levels. Population residing in the extreme northern and southern regions where sun exposure is inadequate have a low level of VD. Air particulate pollution can also reduce sun exposure and also effects $D$ synthesis in the body (47). Nonetheless, $25(\mathrm{OH}) \mathrm{D}_{3}$ deficiency is prevalent worldwide across different latitudes (48); the regions with the greatest deficiency include the Middle East, Asia and Northern Europe. Nonetheless, VD deficiency is prevalent worldwide across different latitudes (48-50); the regions with the greatest VD deficiency include the Middle East, Asia, and Northern Europe (47). In the United States alone, an estimated $40 \%$ of the population has deficient $25(\mathrm{OH}) \mathrm{D}_{3}$ levels (51).

There is little research on the seasonal and latitudinal influences on exposure to sunlight and stroke incidence due to $25(\mathrm{OH}) \mathrm{D}_{3}$ deficiency. Some evidence suggests that $25(\mathrm{OH}) \mathrm{D}_{3}$ deficiency due to low sun exposure at higher altitudes has contributed to greater risk for cardiovascular disease through hypertension (52-54). Similarly, variation in $25(\mathrm{OH}) \mathrm{D}_{3}$ between seasons of low sun exposure (October to March) and high sun exposure (April-September) have been found to be an accurate predictor of coronary artery disease (10). In Greece, the peak incidence of ischemic stroke occurs in spring $(8.4 \%$ above average), whereas summers have the lowest incidence of stroke ( $10.4 \%$ below average); however, there were no significant seasonal differences in intracerebral hemorrhage, subarachnoid hemorrhage, and transient ischemic attack incidence.

There is little research on the seasonal and latitudinal influences on exposure to sunlight and stroke incidence due to VDD. Some evidence suggests that VDD due to low sun exposure at higher altitudes has contributed to greater risk for cardiovascular disease through hypertension $(52,53,55,56)$. Similarly, variation in $25(\mathrm{OH}) \mathrm{D}_{3}$ between seasons of low sun exposure (October to March) and high sun exposure (AprilSeptember) have been found to be an accurate predictor of coronary artery disease $(46,57)$. In Greece, the peak incidence of ischemic stroke occurs in spring ( $8.4 \%$ above average), whereas summers have the lowest incidence of stroke $(10.4 \%$ below average); however, there were no significant seasonal differences in intracerebral hemorrhage, subarachnoid hemorrhage, and transient ischemic attack incidence (56). Additionally, belowmedian sun exposure for a year has been found to significantly increase the risk of stroke incidence [hazard ratio (HR) 1.61] (58). Many stroke studies have already adjusted for sun exposure due to season and/or latitude among many other variables influencing $25(\mathrm{OH}) \mathrm{D}_{3}$ levels $(8,12-14,59-61)$, so the impact of sun exposure alone has yet to be thoroughly studied.

\section{Sex}

Several studies have focused on sex-specific relationships between VD and stroke (11, 60, 62-64). A female retrospective cohort study from 1968 to 2001 involving middle-aged Swedish women born in Gothenburg found that women with $<50 \mathrm{nmol} / \mathrm{L}$ in their blood not only had a higher risk for cardiovascular disease (HR 1.29), but also a significant increase in stroke risk (HR 3.30) and morbidity (HR 1.96) for the first 17 years of the study, after accounting for all confounding variables (62). Inevitably, though, the relative risks converged for all women, indicating that the physiological risks of $25(\mathrm{OH}) \mathrm{D}_{3}$ deficiency peak around 50 to 70 years of age and eventually subside. Many stroke studies have 
already adjusted for sun exposure due to season and/or latitude among many other variables influencing VD levels $(8,12,13,59-$ $61,65,66)$, so the impact of sun exposure alone has yet to be thoroughly studied.

A similar case-cohort study examined 928 female nurses, half of whom were patients with stroke and the other half of whom were the healthy control, from the Nurses' Health Study from 1976 to 2006 (60). It was observed that the women in the lowest tertile of $25(\mathrm{OH}) \mathrm{D}_{3}$ levels $(9.2-45.7 \mathrm{nmol} / \mathrm{L})$ experienced a moderate risk increase for stroke [odds ratio (OR) 1.49], suggesting a modest association between $25(\mathrm{OH}) \mathrm{D}_{3}$ deficiency and stroke risk $(60,66)$. Inevitably, though, the relative risks converged for all women, indicating that the physiological risks of VDD peak around 50 to 70 years of age and eventually subside $(25,62)$. A similar case-cohort study examined 928 female nurses, half of whom were patients with stroke and the other half of whom were the healthy control, from the Nurses' Health Study from 1976 to 2006 (60). Another study examined both males and females enrolled in the National Health and Nutrition Examination Survey from 2001 to 2006 and found that higher $25(\mathrm{OH}) \mathrm{D}_{3}$ levels reduced stroke risk the most for women ages 20 to 50 (OR 0.26) (63), supporting the conclusions of the Swedish cohort study regarding the importance of VD for middle-aged women (62).

In contrast, studies focusing on men, such as a prospective cohort study associated with the Osteoporotic Fractures in Men, found no significant association between $25(\mathrm{OH}) \mathrm{D}_{3}$ levels and risk for cardiovascular or congenital heart disease, although $25(\mathrm{OH}) \mathrm{D}_{3}$ deficiency increased risk for a cerebrovascular or stroke event (HR 1.70) (11). Another prospective cohort study involving middle-aged men, part of the Honolulu Heart Program, found that Japanese men in the lowest quartile of VD intake (0-44.8 IU) had a slight increase in risk for all stroke events (HR 1.22) which includes risk for thromboembolism or ischemic stroke (HR 1.27). There was no significant association with hemorrhagic stroke, and the risk for stroke in $25(\mathrm{OH}) \mathrm{D}_{3}$ deficient middle-aged men is far more modest compared with women (64). The overall research demonstrates that stroke risk for middle-aged $25(\mathrm{OH}) \mathrm{D}_{3}$-deficient women is far more significant and severe than it is for middle-aged men $(11,60,62-$ 64).

\section{Race}

The influence of race on the relationship between VD and stroke is unclear. Relatively few studies have focused exclusively on racial differences in the relationship between VD levels and stroke (67-69). A prospective cohort study, part of the Third National Health and Nutrition Survey from 1988 to 1994, found that while black Americans tended to have significantly lower $25(\mathrm{OH}) \mathrm{D}_{3}$ levels than white Americans, the association between severe $\operatorname{VDD}\left(<15 \mathrm{ng} / \mathrm{ml} 25(\mathrm{OH}) \mathrm{D}_{3}\right)$ and stroke was only significant in whites (HR 2.13) but not in blacks (HR 0.93) (67). However, a more recent retrospective cohort study examining a larger population of 29,653 patients, half-white and half-black, from 2003 to 2007, revealed that VDD individuals $(<20 \mathrm{ng} / \mathrm{ml}$ $\left.25(\mathrm{OH}) \mathrm{D}_{3}\right)$ were more likely than individuals with optimal $\mathrm{VD}\left(>30 \mathrm{ng} / \mathrm{ml} 25(\mathrm{OH}) \mathrm{D}_{3}\right)$ to be stroke victims (HR 1.85), with the relationship decreasing for $\mathrm{VD}$-insufficient individuals
(20-30 ng/ml 25(OH)D 3 ; HR 1.33) (68). Evidence from the Atherosclerosis Risk in Communities study performed across the United States similarly found no significant difference between blacks and whites in the association between $25(\mathrm{OH}) \mathrm{D}_{3}$ levels and stroke risk (69). Despite prior contrary evidence (67), recent findings suggest no racial differences in the relationship between VD and stroke risk $(68,69)$.

There was no significant difference in this inverse association of $25(\mathrm{OH}) \mathrm{D}_{3}$ and stroke risk between races (68). Evidence from the Atherosclerosis Risk in Communities study performed across the United States similarly found no significant difference between blacks and whites in the association between $25(\mathrm{OH}) \mathrm{D}_{3}$ levels and stroke risk (69). Despite prior contrary evidence $(64,69)$, recent findings suggest no racial differences in the relationship between VD and stroke risk $(68,69)$.

\section{Diabetes}

Among non-diabetic patients, there is evidence of a positive correlation between $25(\mathrm{OH}) \mathrm{D}_{3}$ deficiency and stroke risk (25, 70). A Chinese randomized single-blind clinical trial found that $25(\mathrm{OH}) \mathrm{D}_{3}$ deficiency in normoglycemic or non-diabetic patients could increase stroke risk (HR 1.58) (25). Similarly, a Chinese retrospective cohort study found that middle-aged non-diabetic patients with ischemic stroke were over three times more likely to have worse stroke outcomes (OR 3.20) and had almost four times the risk of mortality with $25(\mathrm{OH}) \mathrm{D}_{3}$ deficiency (OR 3.90) (70). However, there is some debate about stroke risk from $25(\mathrm{OH}) \mathrm{D}_{3}$ deficiency among diabetic patients, with some studies suggesting that diabetes is a confounding variable $(12,25)$ and another study finding otherwise. There is also debate about stroke risk from VDD among diabetic patients, with some studies suggesting that diabetes is a confounding variable $(12,25)$ and another study finding otherwise (71). For instance, $25(\mathrm{OH}) \mathrm{D}_{3}$ deficiency was associated with a reduced stroke risk among normoglycemic patients (HR 1.58), but this relationship was not observed in hyperglycemic patients (25). An American 7-year prospective cohort study similarly found that while $25(\mathrm{OH}) \mathrm{D}_{3}$ deficiency is moderately associated with stroke in 65-67-year-old patients (HR 1.30), the risk significantly diminishes after adjusting for diabetes (HR 1.11) (12). A German retrospective cohort study of 1,108 diabetic patients, however, still found $25(\mathrm{OH}) \mathrm{D}_{3}$ deficiency to be a significant risk factor for stroke (HR 2.58), as well as for sudden cardiac death (HR 2.34) (71).

An American 7-year prospective cohort study similarly found that while VDD is moderately associated with stroke in 65-67year-old patients (HR 1.30), the risk significantly diminishes after adjusting for diabetes (HR 1.11) (11). A German retrospective cohort study of 1,108 diabetic patients, however, still found VDD to be a significant risk factor for stroke (HR 2.58), as well as for sudden cardiac death (HR 2.34) (71).

\section{Genetics}

Recent evidence suggests an underlying genetic role in the association between $25(\mathrm{OH}) \mathrm{D}_{3}$ deficiency and stroke $(69,72-74)$. $25(\mathrm{OH}) \mathrm{D}_{3}$ levels are regulated by carrier VD binding proteins (DBP) (5), and genotypes for high DBP single-nucleotide polymorphism (SNP), particularly the G allele of rs7041 and A allele of rs4588, are linked with low $25(\mathrm{OH}) \mathrm{D}_{3}$ levels $(69,72)$. 
Genetic predisposition toward high DBP SNP, particularly with genotypes rs7041 TG/GG (HR 1.29) and rs4588 CA/AA (HR 1.37), is therefore a significant factor in stroke risk through the reduction of $25(\mathrm{OH}) \mathrm{D}_{3}$ serum levels (69). Other genetic variants associated with serum $25(\mathrm{OH}) \mathrm{D}_{3}$ have little significant causal relationship with ischemic stroke $(73,74)$. Such variants include DBP SNPs (rs1155563, rs2282679, rs12785878, and rs3829251), which are linked to below-average $25(\mathrm{OH}) \mathrm{D}_{3}$ and also have no significant influence on other cardiovascular diseases such as myocardial infarction (73). Similarly, mutations in the DHCR7 and CYP2R1 genes, which can genetically predetermine low $25(\mathrm{OH}) \mathrm{D}_{3}$ levels, have a slight association with hypertension (OR 1.02), but no association with ischemic stroke (OR 0.98) (74). Therefore, $25(\mathrm{OH}) \mathrm{D}_{3}$ deficiency and stroke risk does have a genetic component, with variants rs7041 TG/GG and rs4588 CA/AA significantly linked to ischemic stroke risk $(69,72)$.

\section{RANDOMIZED CONTROLLED TRIALS OF VD SUPPLEMENTATION}

The few randomized controlled trial studies examining the efficacy of VD supplementation suggest that VD intake could also improve stroke outcome and cardiovascular function. A non-blinded randomized controlled trial on $25(\mathrm{OH}) \mathrm{D}_{3}$ deficient and -insufficient stroke patients tested the effects of administering single doses of 600,000 IU of Cholecalciferol Intramuscular injections (75). The experimental group's mean functional outcomes at 3 months improved by 6.39 points on the Scandinavian Stroke Scale, whereas the control group improved by only 2.5 points (75). The results of this study, however, are questionable due to the non-blinded nature of the trial. Another randomized controlled trial tested VDcalcium supplementation; after 6 months, $25(\mathrm{OH}) \mathrm{D}_{3}$-deficient patients with supplementation had a decreased mortality risk (HR 0.26) compared with the control group and were more likely to attain a good mRS functional outcome (OR 1.90) (76). However, at doses of 2,000 IU per day for 5 years, as tested in a nationwide randomized, placebo-controlled trial, VD supplementation failed to reduce the incidence of cardiovascular events and mortality (77).

A significant body of randomized controlled trials has examined vascular outcomes from VD treatment. A randomized, placebo-controlled trial found that for overweight/obese $25(\mathrm{OH}) \mathrm{D}_{3}$-deficient patients, higher dosage supplementation was associated with decreased mean carotid-femoral PWV and carotid-radial PWV, whereas the placebo group had significantly higher arterial pressure (78). This reduction in PWV is consistent with the proposed protective mechanism of $\mathrm{VD}$ against cardiovascular disease via arterial pressure reduction $(20,23)$. Large single doses of $\mathrm{VD}$ show mixed improvement in flow-mediated dilation (FMD). One clinical controlled trial that administered a monthly 300,000 IU VD supplement to $25(\mathrm{OH}) \mathrm{D}_{3}$-deficient patients $(<25 \mathrm{nmol} / \mathrm{L})$ found significant improvements in FMD and thiobarbituric acid-reactive substances (TBARS) after treatment; however, the study was not randomized and placebo-controlled (79).
When patients were administered single doses of VD2 (100,000 IU) to patients with stroke history in a randomized, placebocontrolled, double-blind trial, FMD improved from 3.7 to $6.9 \%$ after 8 weeks (80). Furthermore, large single dosages of VD supplementation could assist $25(\mathrm{OH}) \mathrm{D}_{3}$-deficient patients with comorbidities. A double-blind, parallel group, randomized, placebo-controlled trial that administered a one-time dose of 100,000 IU VD2 on $25(\mathrm{OH}) \mathrm{D}_{3}$-deficient, Type 2 diabetic patients found improvement in FMD compared with the placebo (81). Children between 3 and 20 years old with chronic kidney disease and $25(\mathrm{OH}) \mathrm{D}_{3}$ deficiency likewise had a significant increase in FMD. Endothelium-independent FMD, a measure of arterial stiffness, after cholecalciferol supplementation significantly decreased in an interventional study (82).

However, as noted previously, a relatively lower dose of VD administered frequently does not necessarily lead to improved endothelial outcome. The daily administration of 2,500 IU of VD3 for 4 months to $25(\mathrm{OH}) \mathrm{D}_{3}$-deficient women resulted in no FMD and PWV differences between experimental and placebo groups (83). Likewise, a higher daily dosage of 5,000 IU for 12 weeks for Type 2 diabetic patients, who have benefitted from large, single VD doses (81), led to few significant improvements in FMD, circulating endothelial progenitor cells, or PWV (84). Daily statin use, which increases serum $25(\mathrm{OH}) \mathrm{D}_{3}$ levels similarly to VD supplements, can reduce carotid intima-media thickness and increase circulation of endothelial progenitor cells but has failed to significantly improve FMD (85).

Furthermore, VD and calcium supplementation may have negative (86) to negligible (87-89) effects. Recent evidence suggests an underlying genetic role in the association between VDD and stroke $(20,31-33,69,72-74) .25(\mathrm{OH}) \mathrm{D}_{3}$ levels are regulated by carrier VD binding proteins (DBP) (5), and genotypes for high DBP single-nucleotide polymorphism (SNP), particularly the $\mathrm{G}$ allele of rs7041 and A allele of rs4588, are linked with low $25(\mathrm{OH}) \mathrm{D}_{3}$ levels $(69,72)$. Genetic predisposition toward high DBP SNP, particularly with genotypes rs7041 TG/GG (HR 1.29) and rs4588 CA/AA (HR 1.37), is therefore a significant factor in stroke risk through the reduction of $25(\mathrm{OH}) \mathrm{D}_{3}$ serum levels (69). Other genetic variants associated with serum $25(\mathrm{OH}) \mathrm{D}_{3}$ have little significant causal relationship with ischemic stroke $(73,74)$. Such variants include DBP SNPs (rs1155563, rs2282679, rs12785878, and rs3829251), which are linked to below average $25(\mathrm{OH}) \mathrm{D}_{3}$ and also have no significant influence on other cardiovascular diseases such as myocardial infarction (73). Similarly, mutations in the DHCR7 and CYP2R1 genes, which can genetically predetermine low $25(\mathrm{OH}) \mathrm{D}_{3}$ levels, have a slight association with hypertension (OR 1.02), but no association with ischemic stroke (OR 0.98) (74). Therefore, VDD and stroke risk does have a genetic component, with variants rs7041 TG/GG and rs4588 CA/AA significantly linked to ischemic stroke risk $(69,72)$.

\section{Functional Outcomes and VD on Brain Protection}

Prospective population health studies observing dietary intake have previously noted that dietary intake of VD in middle-aged 


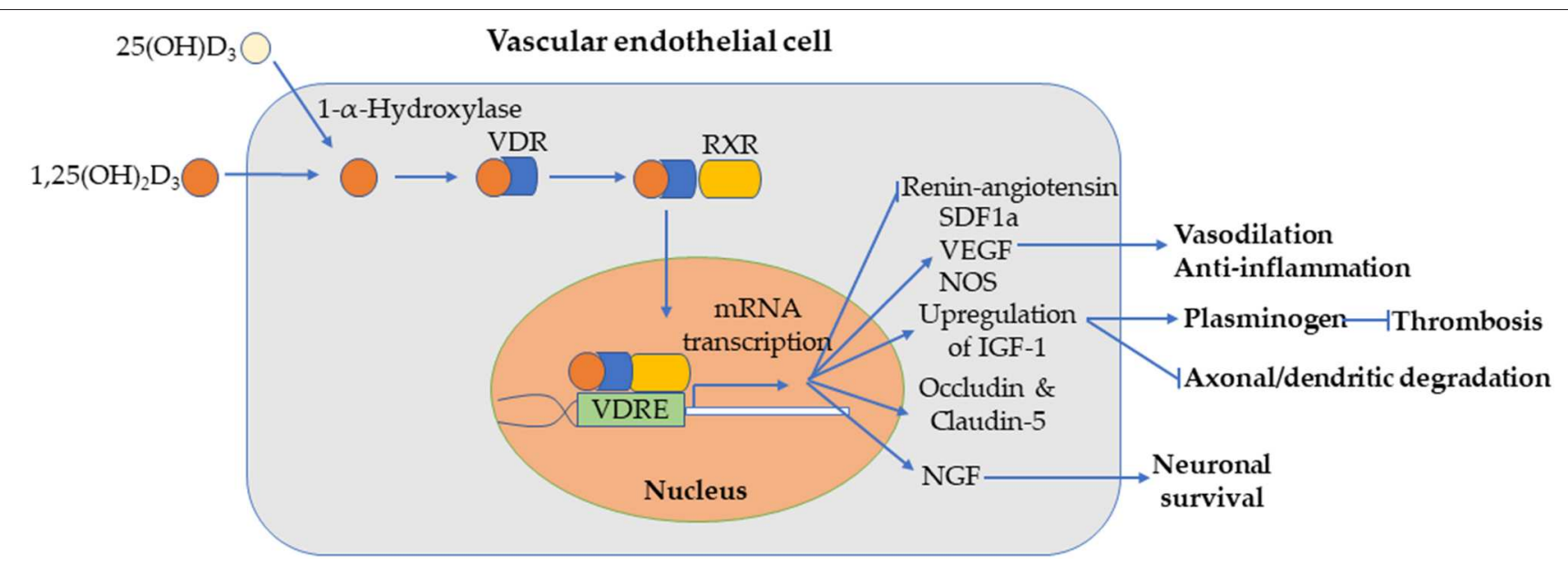

FIGURE 1 | Combination of various proposed mechanisms in endothelial cells for vitamin $\mathrm{D}$ prevention/mitigation of ischemic stroke. 1,25(OH) $\mathrm{D}_{3}$ [or $25(\mathrm{OH}) \mathrm{D}_{3} \mathrm{D} 3$, which is converted to of $1,25(\mathrm{OH})_{2} \mathrm{D}_{3}$ via $1-\alpha$-Hydroxylase] diffuses through the endothelial cell membrane, binds to vitamin $\mathrm{D}$ receptor (VDR), dimerizes with $\mathrm{RXR}$, and translocates into the nucleus. The complex binds to VDRE for transcription of genes resulting in inhibition of renin-angiotensin and activation of SDF1a, VEGF, and NOS pathways for vasodilation and anti-inflammation; upregulation of IGF-1 (and thus neuroprotection of axon and dendrites and thrombolysis via plasminogen); expression of blood brain barrier (BBB) tight-junction proteins occludin and claudin-5; upregulation of nerve growth factor (NGF), which supports neuronal growth, maintenance, and survival.

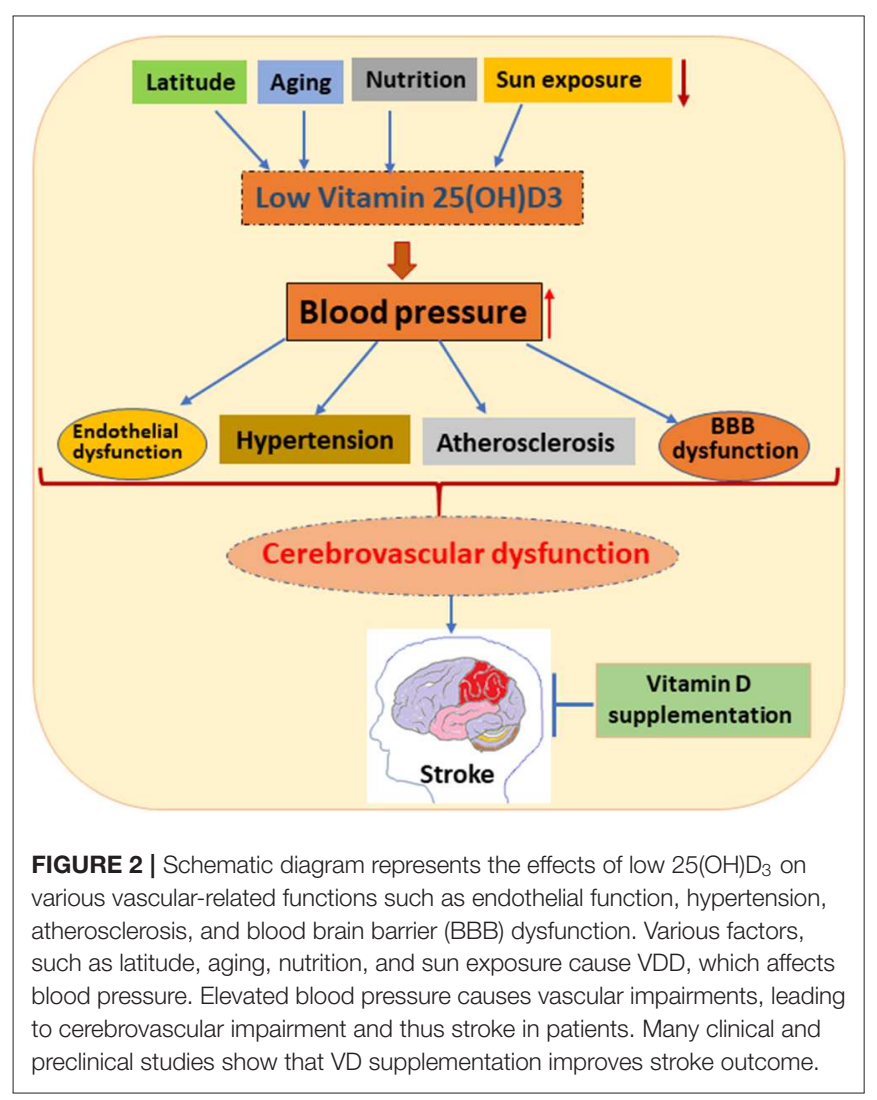

to senior populations has reduced the risk of stroke incidence and mortality $(42,43)$. The few randomized controlled trials examining the efficacy of VD supplementation suggest that VD
TABLE 1 | Summary of vitamin D benefits, mechanisms, supplementation.

\begin{tabular}{|c|c|c|}
\hline $\begin{array}{l}\text { Associations with } \\
\text { ischemic stroke }\end{array}$ & Proposed mechanisms & $\begin{array}{l}\text { Recommended } \\
\text { supplementation }\end{array}$ \\
\hline $\begin{array}{l}\text { - Lowered risk } \\
\text { - Reduced severity } \\
\text { - Improvement in } \\
\text { mental and physical } \\
\text { outcome } \\
\text { - Reduced recurrence } \\
\text { and mortality }\end{array}$ & $\begin{array}{l}\text { - NO pathway } \\
\circ \text { Vasodilation } \\
\text { - Inhibit renin-angiotensin } \\
\text { (vasoconstriction) } \\
\text { - Maintains BBB integrity } \\
\text { - IGF-1 and other growth } \\
\text { factor pathways } \\
\text { - Prevents axon/dendrite } \\
\text { degeneration } \\
\text { - Antithrombosis } \\
\text { (plasminogen) } \\
\text { - Others }\end{array}$ & $\begin{array}{l}\text { - Adults: } 100,000- \\
300,000 \mathrm{IU} \\
(2,500-7,500 \mathrm{mcg}) \\
\text { monthly } \\
\text { - } \geq 30 \mathrm{ng} / \mathrm{ml} \text { serum } \\
25(\mathrm{OH}) \mathrm{D}_{3} \text { optimal }\end{array}$ \\
\hline
\end{tabular}

*Values based on positive results for single large doses $(81,82)$.

intake could also improve stroke outcome and cardiovascular function (Figure 1).

Furthermore, VD and calcium supplementation may have negative (86) to negligible $(87,89,90)$ effects. A meta-analysis combining data from the Women's Health Initiative and eight other studies, encompassing 28,072 patients, found that calcium supplementation, with or without VD, could modestly increase the risk of myocardial infarction and stroke (86). It is theorized that the increased serum calcium levels from dietary intake could lead to carotid artery plaque thickness and aortic calcification (86). However, an observational cohort study on VD and calcium supplementation found no increase in the incidence of myocardial infarction, stroke, or mortality for women who have consistently received supplementation after 2 years, relative to women who received minimal supplementation (87). A recent nested case-control study from the American Heart Association 
TABLE 2 | Effects of low vitamin D on stroke outcomes.

Patients with vitamin D deficiency
Patients with low serum 25-(OH)D
Children with 25(OH)D concentrations <30 ng/mL
Low plasma levels calcidiol (vitamin D metabolite)
Vitamin D deficiency with serum 25(OH) vitamin D
levels <20 ng/mL
$25(O H) D$ deficiency [defined as serum 25(OH)D levels
$<20$ ng/mL]
25-dihydroxyvitamin D (25-OH D) levels 25-OH D
deficiency (<15 ng/mL, <10 ng/mL)
Low levels of 25 -hydroxyvitamin D (25[OH]D)
Low 25(OH)VitD
insufficient (10-20 ng/mL)
Low 25-hydroxyvitamin D levels (25[OH]D)
Low serum $25-$ dihydroxyvitamin D levels
Low 25-hydroxyvitamin D (25[OH]D) (<12 ng/mL)

Low levels of 25(OH)D and 1,25(OH)2D

Low dietary vitamin $\mathrm{D}$ intake or serum

25-hydroxyvitamin $D$ deficiency

Deficiency of 25-hydroxyvitamin D

Low 25-hydroxyvitamin D concentrations

Low serum 25-hydroxyvitamin D [25(OH)D]

Non-diabetic with vitamin 25-hydroxyvitamin D $(25(\mathrm{OH}) \mathrm{n} / \mathrm{a}$

D) deficiency

Low 25-hydroxyvitamin D [25(OH)D]

Hemodialysis, diabetes

Low serum 25(OH)D

Low serum 25(OH)D level. The mean 25(OH)D level was $47.2 \pm 31.7 \mathrm{nmol} / \mathrm{l}$, and most patients met vitamin $D$ deficient status ( $<50 \mathrm{nmol} / \mathrm{l})$

Low serum 25-Hydroxyvitamin D (25(OH)D)

The mean level of 25(OH)D was significantly lower in the chronic group than in the subacute group (12.3 vs. $16.3 \mathrm{ng} / \mathrm{mL}$.

Low concentrations of plasma 25-hydroxyvitamin D $(25(\mathrm{OH}) \mathrm{D})$ and genetic variants in DHCR7/ CYP2R1 Low serum levels of $25(\mathrm{OH}) \mathrm{D}$

Vascular risk factors nutrition

\section{Comorbid conditions/ secondary outcomes}

Metabolic syndrome

Severe obesity

Sun exposure, coronary artery disease, and hypertension

Poor health behaviors, comorbid health conditions, and potential biological mediators

Smoking status, hypertension, diabetes, elevated low-density lipoprotein cholesterol, hypertriglyceridemia, low high-density lipoprotein cholesterol, chronic kidney disease

$\mathrm{n} / \mathrm{a}$

Cardiovascular, musculoskeletal, infectious, autoimmune, and malignant diseases

Air pollution and low sunlight exposure along with severe malnutrition

$\mathrm{n} / \mathrm{a}$

Adverse effects on neurocognitive health and stroke (with and without dementia symptoms)

Diabetes mellitus, hypertension, and cancer

Musculoskeletal health

Elevated cardiovascular disease risk
Cardiovascular risk /Stroke incidence

Increased cardiovascular risk in patients $(4,95)$

Increased cardiovascular risk (8)

Development of acute ischemic events (acute coronary syndrome, stroke, or transient ischemic attack) (8)

Higher risk of cerebrovascular and cardiovascular events such as heart failure, myocardial infarction, stroke, or cardiovascular death $(11,12,96)$

Increased risk of cardiovascular disease (13)

Increase in cardiovascular risk (15)

Cerebrovascular disease and stroke (17)

High risk of cardiovascular disease and stroke $(18,47,58)$

Increased risk of ischemic stroke not hemorrhagic stroke (19)

Cerebrovascular disease and Cardiovascular disease (CVD) stroke $(57,97)$

CVD with $26 \%$ increased rate of all-cause mortality (65) Acute stroke $(59,59)$

29\% higher CVD risk and 3.3-fold elevated risk of ischemic stroke while higher vitamin D levels were significantly associated with reduced risk of stroke $(60,66)$

History of previous cerebrovascular disease events Age, calories, body mass index, hypertension, diabetes, Increased all stroke, thromboembolic ischemic stroke

smoking, physical activity, serum cholesterol, alcohol $\quad(25,64)$ intake and low high-density lipoprotein cholesterol

Cardiovascular disease events and mortality

There were no statistically significant differences in the association of stroke in black vs. white participants Atherosclerosis Risk in Communities

Multivariable analyses showed that the risk for a poor 90-day outcome doubled with each $10-\mathrm{ng} / \mathrm{mL}$ decrease in serum 25(OH)D

Intravenous thrombolysis

Patients with a history of total parenteral nutrition had lower 25(OH)D levels than subjects who had enteral

Cardiovascular disease (CVD) risk, myocardial infarction, high blood pressure, hypertension, and Increased risk of cardiovascular disease
The risk of fatal stroke was greater in blacks compared with whites (67).

Increased risk of stroke in patients with

25-hydroxyvitamin D <20 ng/mL (68)

The lowest quintile of $25(\mathrm{OH}) \mathrm{D}(<17.2 \mathrm{ng} / \mathrm{ml})$ was associated with higher stroke risk (69)

Increased poor functional outcome events in Chinese non-diabetic stroke individuals (70)

Severe vitamin D deficiency was strongly associated with stroke, cardiovascular events, and mortality $(71,98)$

Low levels associated with large volume infarcts Higher serum 25(OH)D concentration was associated with smaller infarct volumes (20)

Increased stroke severity in patients $(20,31)$

Worse functional acute ischemic stroke outcomes (32) Onset of stroke (33)

Increased risk of ischemic stroke $(73,74)$

Levels were observed to be prognostic markers of cardiovascular disease and all-cause mortality in Chinese patients with ischemic stroke or risk of recurrent stroke $(21,22)$ 
TABLE 2 | Continued

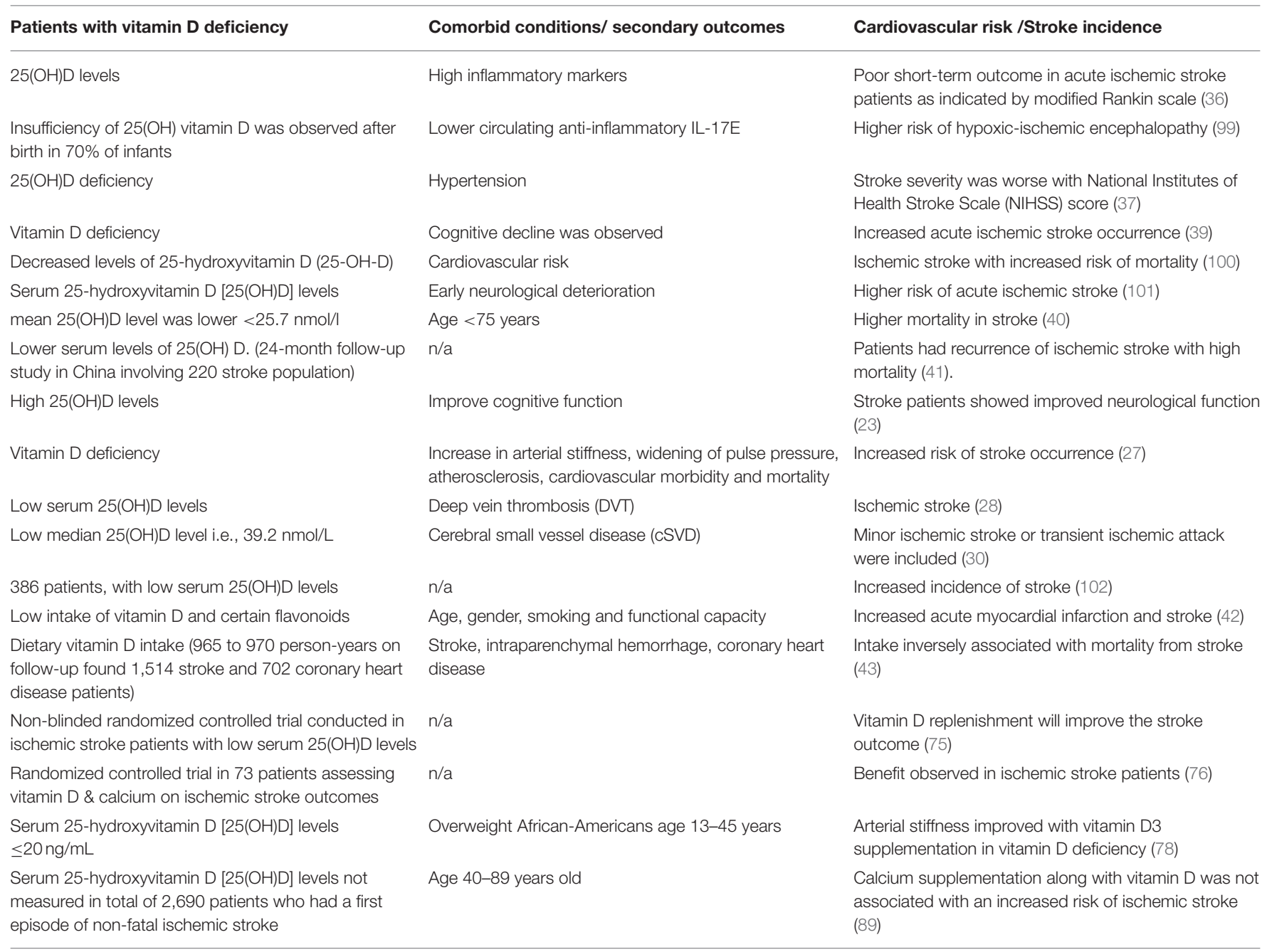

further clarifies prior findings $(86,87)$ by noting that high daily calcium supplementation $(\geq 1,000 \mathrm{mg})$ may lead to an increased risk of ischemic stroke, but the combination of VD supplementation negates such risk (89). It is likely that VD absorption of calcium prevents high serum calcium $(3,4)$ and the corresponding artery plaque thickness and aortic calcification.

Meta-analyses on VD-only supplementation studies have similarly found mixed results $(81,82)$, as have metaanalyses of randomized controlled trials studying VD-alone supplementation (91-94). One found that VD supplementation did not significantly improve FMD overall, but supplementation was found to be most effective in studies that lasted $<16$ weeks (suggesting only short-term benefits) and with patients with systolic blood pressure $>140 \mathrm{mmHg}$ and diastolic blood pressure $<80 \mathrm{mmHg}$ (91). Likewise, a smaller meta-analysis suggested that VD supplementation may improve FMD, although the p-value (0.054) was too high to be significant; the authors believed that more studies were required for significance (92). A systematic review and individual participant meta-analysis found no significant impact from VD3 supplementation on FMD and PWV, although higher doses of supplementation can create a slightly greater treatment effect on FMD, along with modest improvement for microvascular function (93). These results were supported by a similar systematic review and meta-analysis of randomized controlled trials, which found improvement in FMD, although not in PWV and augmentation index, for metabolic syndrome patients receiving VD supplementation (94).

\section{DISCUSSION}

The body of literature examined mostly consists of retrospective or prospective studies analyzing the relative risk of ischemic stroke or cardiovascular disease in general from $25(\mathrm{OH}) \mathrm{D}_{3}$ levels. Relatively few randomized controlled trials directly investigate the effects of VD supplementation, and they have small sample sizes. Other supplemental randomized controlled studies that examine significantly larger populations tend to focus on calcium supplementation. Further randomized controlled trials strictly examining VD supplementation with larger sample sizes would provide clearer insight on the clinical implications for stroke treatment and prevention (Figure 2, Tables 1, 2). 
One crucial advantage of this review is that the population health studies examined encompass broad demographic diversity within the United States, as well as in Europe, Africa, China, and India for insights in global health, especially in developing, middle-income nations with growing stroke incidence. However, differences in environmental and socioeconomic conditions make comparisons and syntheses of international data difficult.

Furthermore, most research does not explore $1,25(\mathrm{OH})_{2} \mathrm{D}_{3}$ 's neuroprotective pathways in depth. Additional research on $1,25(\mathrm{OH})_{2} \mathrm{D}_{3}$ 's mechanisms could explain how $1,25(\mathrm{OH})_{2} \mathrm{D}_{3}$ mitigates the onset, severity, and functional outcomes of ischemic stroke. A causal relationship could be conclusively established if such mechanisms were fully explained. The various theories of neuroprotection may indicate which aspects of $1,25(\mathrm{OH})_{2} \mathrm{D}_{3}$ 's physiological roles to examine, including growth factor expression, antithrombotic effects, and vasodilation to encourage blood flow. In addition, determining the mechanisms that explain the influence of variables such as sex and genetics would also be necessary for further investigation. The variable that has been least studied concerning stroke incidence is sun exposure. Much more research into stroke risk and $25(\mathrm{OH}) \mathrm{D}_{3}$ levels due to relative sun exposure (accounting for differences in geography, seasons, and other sub-factors) would offer significant clinical insight for stroke care and prevention in different regions.

Overall, this paper adds to the current knowledge of VD and ischemic stroke by synthesizing research on the relationship between $25(\mathrm{OH}) \mathrm{D}_{3}$ deficiency and stroke incidence, as well as the efficacy of supplementation for clinical treatment. Additional risk factors, including race, sex, and genetics, have all been incorporated into the analysis of stroke incidence, clarifying how such variables interact with $25(\mathrm{OH}) \mathrm{D}_{3} \mathrm{D} 3$ serum levels and contribute to stroke risk. Examining the results of the nascent research on supplementation may provide direction for future research.

\section{CONCLUSIONS AND FUTURE DIRECTION}

$25(\mathrm{OH}) \mathrm{D}_{3}$ deficiency levels are a significant risk factor for ischemic stroke and may have prognostic value, especially for

\section{REFERENCES}

1. Kim AS, Johnston SC. Temporal and geographic trends in the global stroke epidemic. Stroke. (2013) 44:S123-5. doi: 10.1161/STROKEAHA.111.000067

2. Feigin VL, Norrving B, Mensah GA. Global burden of stroke. Circ Res. (2017) 120:439-48. doi: 10.1161/CIRCRESAHA.116.308413

3. Al Mheid I, Quyyumi AA. Vitamin D and cardiovascular disease: Controversy unresolved. J Am Coll Cardiol. (2017) 70:89-100. doi: 10.1016/j.jacc.2017.05.031

4. Alkhatatbeh MJ, Abdul-Razzak KK, Khasawneh LQ, Saadeh NA. High prevalence of vitamin D deficiency and correlation of serum vitamin $\mathrm{D}$ with cardiovascular risk in patients with metabolic syndrome. Metab Syndr Relat Disord. (2017) 15:213-9. doi: 10.1089/met.2017. 0003

5. Kongsbak M, Levring TB, Geisler C, von Essen MR. The vitamin $\mathrm{D}$ receptor and $\mathrm{T}$ cell function. Front Immunol. (2013) 4:148. doi: 10.3389/fimmu.2013.00148 women and individuals with particular DBP SNPs. Worsening stroke severity and outcomes have also been associated with $25(\mathrm{OH}) \mathrm{D}_{3}$ deficiency (43-50). VD supplementation may reduce ischemic stroke risk and outcomes, but findings remain mixed, especially when considering the detrimental effects of high calcium supplementation. These findings highlight the need for randomized controlled trials to determine whether VD supplementation in patients with deficiency could be beneficial for the primary or secondary prevention of cardiovascular and cerebrovascular events. With high prevalence globally, VDD is not uncommon. It is associated with adverse health-related problems. Randomized controlled trials are therefore urgently needed to evaluate whether VD supplementation reduces the incidence of strokes and improves the outcome of poststroke patients.

\section{AUTHOR CONTRIBUTIONS}

KY proposed the topic of the review and provided guidance in the research process. NM reviewed the literature and drafted the paper with input and critical review from all authors. SD provided guidance in the research and writing process with suggestions on areas of investigation.

\section{FUNDING}

This study was supported in part by the National Institutes of Health (R01AT007429, R01NS046400, R21NS095166, R21NS110008), the American Heart Association (17GRNT33450010) and the Brain Aneurysm Foundation.

\section{ACKNOWLEDGMENTS}

We would like to thank members of the SD Laboratories and the University of Florida Center for Translational Research in Neurodegenerative Disease.

6. Feldman D, Pike JW, Glorieux F. Vitamin D. 2nd ed. Philadelphia, PA: Elsevier (2005).

7. Institute of Medicine (US) Committee to Review Dietary Reference Intakes for Vitamin D Calcium. In: Ross AC, Taylor CL, Yaktine AL, editors. Dietary Reference Intakes for Calcium Vitamin D. Del Valle Washington, DC: National Academies Press (US) (2011).

8. Iqbal AM, Dahl AR, Lteif A, Kumar S. Vitamin D deficiency: a potential modifiable risk factor for cardiovascular disease in children with severe obesity. Children (Basel). (2017) 4:80. doi: 10.3390/children4090080

9. Wojcik M, Janus D, Kalicka-Kasperczyk A, Sztefko K, Starzyk JB. The potential impact of the hypovitaminosis D on metabolic complications in obese adolescents - preliminary results. Ann Agric Environ Med. (2017) 24:636-9. doi: 10.5604/12321966.1230676

10. Aceña A, Franco-Peláez JA, Gutierrez-Landaluce C, Pello AM, Cristóbal C, Tarín N, et al. Sun exposure influences the prognostic power of components of mineral metabolism in patients with coronary artery disease. Nutr Metab Cardiovasc Dis. (2017) 27:762-7. doi: 10.1016/j.numecd.2017.06.006 
11. Bajaj A, Stone KL, Peters K, Parimi N, Barrett-Connor E, Bauer D, et al. Circulating vitamin D, supplement use, and cardiovascular disease risk: the MrOS sleep study. J Clin Endocrinol Metab. (2014) 99:325662. doi: 10.1210/jc.2013-4178

12. Welles CC, Whooley MA, Karumanchi SA, Hod T, Thadhani R, Berg AH, et al. Vitamin D deficiency and cardiovascular events in patients with coronary heart disease: Data from the Heart and Soul Study. Am J Epidemiol. (2014) 179:1279-87. doi: 10.1093/aje/kwu059

13. Kendrick J, Targher G, Smits G, Chonchol M. 25-Hydroxyvitamin D deficiency is independently associated with cardiovascular disease in the Third National Health and Nutrition Examination Survey. Atherosclerosis. (2009) 205:255-60. doi: 10.1016/j.atherosclerosis.2008.10.033

14. Chan R, Chan D, Woo J, Ohlsson C, Mellström D, Kwok T, et al. Serum 25-hydroxyvitamin D and parathyroid hormone levels in relation to blood pressure in a cross-sectional study in older Chinese men. J Hum Hypertens. (2012) 26:20-27. doi: 10.1038/jhh.2010.126

15. Wang TJ, Pencina MJ, Booth SL, Jacques PF, Ingelsson E, Lanier K, et al. Vitamin D deficiency and risk of cardiovascular disease. Circulation. (2008) 117:503-11. doi: 10.1161/CIRCULATIONAHA.107.706127

16. Drezner MK, Rosen CJ, Mulder JE. Patient education: Vitamin D deficiency (Beyond the Basics). Available online at: https://www.uptodate.com/ contents/vitamin-d-deficiency-beyond-the-basics (accessed July 4, 2019)

17. Pilz S, Tomaschitz A, Drechsler C, Zittermann A, Dekker JM, März W. Vitamin D supplementation: a promising approach for the prevention and treatment of strokes. Curr Drug Targets. (2011) 12:88-96. doi: 10.2174/138945011793591563

18. Makariou SE, Michel P, Tzoufi MS, Challa A, Milionis HJ. Vitamin D and stroke: promise for prevention and better outcome. Curr Vasc Pharmacol. (2014) 12:117-24. doi: 10.2174/15701611113119990119

19. Zhou R, Wang M, Huang H, Li W, Hu Y, Wu T. Lower vitamin D status is associated with an increased risk of ischemic stroke: a systematic review and meta-analysis. Nutrients. (2018) 10:277. doi: 10.3390/nu10030277

20. Turetsky A, Goddeau RP, Henninger N. Low serum vitamin $\mathrm{D}$ is independently associated with larger lesion volumes after ischemic stroke. J Stroke Cerebrovasc Dis. (2015) 24:155563. doi: 10.1016/j.jstrokecerebrovasdis.2015.03.051

21. Huang $H$, Zheng $T$, Wang $S$, Wei L, Wang $Q$, Sun $Z$. Serum 25-hydroxyvitamin $\mathrm{D}$ predicts early recurrent stroke in ischemic stroke patients. Nutr Metab Cardiovasc Dis. (2016) 26:908-14. doi: 10.1016/j.numecd.2016.06.009

22. Nie Z, Ji X-C, Wang J, Zhang H-X. Serum levels of 25-hydroxyvitamin D predicts infarct volume and mortality in ischemic stroke patients. $J$ Neuroimmunol. (2017) 313:41-5. doi: 10.1016/j.jneuroim.2017.10.002

23. Yalbuzdag SA, Sarifakioglu B, Afsar SI, Celik C, Can A, Yegin T, et al. Is $25(\mathrm{OH}) \mathrm{D}$ associated with cognitive impairment and functional improvement in stroke? a retrospective clinical study. J Stroke Cerebrovasc Dis. (2015) 24:1479-86. doi: 10.1016/j.jstrokecerebrovasdis.2015.03.007

24. Won S, Sayeed I, Peterson BL, Wali B, Kahn JS, Stein DG. Vitamin D prevents hypoxia/reoxygenation-induced blood-brain barrier disruption via vitamin D receptor-mediated NF-kB signaling pathways. PLoS ONE. (2015) 10:e0122821. doi: 10.1371/journal.pone.0122821

25. Xu T, Zhong C, Xu T, Peng Y, Bu X, Chen C-S, et al. Serum 25hydroxyvitamin $\mathrm{D}$ deficiency predicts long-term poor prognosis among ischemic stroke patients without hyperglycaemia. Clin Chim Acta. (2017) 471:81-5. doi: 10.1016/j.cca.2017.05.020

26. Kashefiolasl S, Leisegang M, Helfinger V, Schürmann C, Müller BP, Randriamboavonjy $\mathrm{V}$, et al. Vitamin D - A new perspective in treatment of cerebral vasospasm. In: 15th International Conference on Subarachnoid Hemorrhage (Amsterdam).

27. Suthar OP, Mathur S, Gupta V, Agarwal H, Mathur A, Singh P, et al. Study of correlation of serum vitamin D levels with arterial stiffness and cardiovascular morbidity in elderly individuals of Western Rajasthan. J Assoc Physicians India. (2018) 66:18-21. Available online at: https://www.japi.org/ march_2018/4_oa_Study_of_Correlation.pdf

28. $\mathrm{Wu} \mathrm{W}-\mathrm{X}, \mathrm{He} \mathrm{D}-\mathrm{R}$. Low vitamin $\mathrm{D}$ levels are associated with the development of deep venous thromboembolic events in patients with ischemic stroke. Clin Appl Thromb Hemost. (2018) 24:69S-75. doi: 10.1177/10760296187 86574
29. Sayeed I, Turan N, Stein DG, Wali B. Vitamin D deficiency increases bloodbrain barrier dysfunction after ischemic stroke in male rats. Exp Neurol. (2019) 312:63-71. doi: 10.1016/j.expneurol.2018.11.005

30. Feng C, Tang N, Huang H, Zhang G, Qi X, Shi F. 25-Hydroxy vitamin $\mathrm{D}$ level is associated with total MRI burden of cerebral small vessel disease in ischemic stroke patients. Int J Neurosci. (2019) 129:4954. doi: 10.1080/00207454.2018.1503182

31. Park KY, Chung PW, Kim YB, Moon HS, Suh BC, Won YS, et al. Serum Vitamin D status as a predictor of prognosis in patients with acute ischemic stroke. Cerebrovasc Dis. (2015) 40:73-80. doi: 10.1159/000434691

32. Daumas A, Daubail B, Legris N, Jacquin-Piques A, Sensenbrenner B, Denimal D, et al. Association between admission serum 25-hydroxyvitamin D levels and functional outcome of thrombolyzed stroke patients. J Stroke Cerebrovasc Dis. (2016) 25:907-13. doi: 10.1016/j.jstrokecerebrovasdis.2016. 01.005

33. Kim K, Cho KH, Im SH, Choi J, Yu J, Kim M. Decrement of serum vitamin D level after stroke. Ann Rehabil Med. (2017) 41:94450. doi: 10.5535/arm.2017.41.6.944

34. Alfieri DF, Lehmann MF, Oliveira SR, Flauzino T, Delongui F, de Araújo MCM, et al. Vitamin D deficiency is associated with acute ischemic stroke, Creactive protein, and short-term outcome. Metab Brain Dis. (2017) 32:493502. doi: 10.1007/s11011-016-9939-2

35. Markišić M, Pavlović AM, Pavlović DM. The impact of homocysteine, vitamin B12, and vitamin D levels on functional outcome after first-ever ischaemic stroke. Biomed Res Int. (2017) 2017:5489057. doi: 10.1155/2017/5489057

36. Wang Y, Ji H, Tong Y, Zhang Z. Prognostic value of serum 25hydroxyvitamin D in patients with stroke. Neurochem Res. (2014) 39:13327. doi: 10.1007/s11064-014-1316-0

37. Zhang B, Wang Y, Zhong Y, Liao S, Lu Z. Serum 25-hydroxyvitamin D deficiency predicts poor outcome among acute ischemic stroke patients without hypertension. Neurochem Int. (2018) 118:91-5. doi: 10.1016/j.neuint.2018.05.001

38. Lelli D, Pérez Bazan LM, Calle Egusquiza A, Onder G, Morandi A, Ortolani E, et al. 25(OH) vitamin D and functional outcomes in older adults admitted to rehabilitation units: the safari study. Osteoporos Int. (2019) 30:88795. doi: 10.1007/s00198-019-04845-7

39. Chen H, Liu Y, Huang G, Zhu J, Feng W, He J. Association between vitamin $\mathrm{D}$ status and cognitive impairment in acute ischemic stroke patients: a prospective cohort study. Clin Interv Aging. (2018) 13:25039. doi: 10.2147/CIA.S187142

40. Daubail B, Jacquin A, Guilland J-C, Khoumri C, Aboa-Eboulé C, Giroud $\mathrm{M}$, et al. Association between serum concentration of vitamin $\mathrm{D}$ and 1-year mortality in stroke patients. Cerebrovasc Dis. (2014) 37:3647. doi: $10.1159 / 000362534$

41. Qiu H, Wang M, Mi D, Zhao J, Tu W, Liu Q. Vitamin D status and the risk of recurrent stroke and mortality in ischemic stroke patients: data from a 24-month follow-up study in China. J Nutr Health Aging. (2017) 21:766-71. doi: 10.1007/s12603-016-0821-z

42. Marniemi J, Alanen E, Impivaara O, Seppänen R, Hakala P, Rajala $\mathrm{T}$, et al. Dietary and serum vitamins and minerals as predictors of myocardial infarction and stroke in elderly subjects. Nutr Metab Cardiovasc Dis. (2005) 15:188-97. doi: 10.1016/j.numecd.2005. 01.001

43. Sheerah HA, Eshak ES, Cui R, Imano H, Iso H, Tamakoshi A, et al. Relationship between dietary vitamin $\mathrm{D}$ and deaths from stroke and coronary heart disease: the Japan Collaborative Cohort Study. Stroke. (2018) 49:45457. doi: 10.1161/STROKEAHA.117.019417

44. Kheiri B, Abdalla A, Osman M, Ahmed S, Hassan M, Bachuwa G. Vitamin $\mathrm{D}$ deficiency and risk of cardiovascular diseases: a narrative review. Clin Hypertens. (2018) 24:9. doi: 10.1186/s40885-018-0105-5

45. Hossein-nezhad A, Holick MF. Vitamin D for health: a global perspective. Mayo Clin Proc. (2013) 88:720-55. doi: 10.1016/j.mayocp.2013. 05.011

46. Hagenau T, Vest R, Gissel TN, Poulsen CS, Erlandsen M, Mosekilde L, et al. Global vitamin D levels in relation to age, gender, skin pigmentation and latitude: an ecologic meta-regression analysis. Osteoporos Int. (2009) 20:133-40. doi: 10.1007/s00198-008-0626-y 
47. Hoseinzadeh E, Taha P, Wei C, Godini H, Ashraf GM, Taghavi M, et al. The impact of air pollutants, UV exposure and geographic location on vitamin D deficiency. Food Chem Toxicol. (2018) 113:24154. doi: 10.1016/j.fct.2018.01.052

48. Mithal A, Wahl DA, Bonjour JP, Burckhardt P, Dawson-Hughes B, Eisman JA, et al. Global vitamin D status and determinants of hypovitaminosis D. Osteoporos Int. (2009) 20:1807-20. doi: 10.1007/s00198-009-0954-6

49. Akhtar S. Vitamin D status in south asian populations - risks and opportunities. Crit Rev Food Sci Nutr. (2016) 56:192540. doi: $10.1080 / 10408398.2013 .807419$

50. Saggese G, Vierucci F, Boot AM, Czech-Kowalska J, Weber G, Camargo CA, et al. Vitamin D in childhood and adolescence: an expert position statement. Eur J Pediatr. (2015) 174:565-76. doi: 10.1007/s00431-015-2524-6

51. Parva NR, Tadepalli S, Singh P, Qian A, Joshi R, Kandala H, et al. Prevalence of Vitamin D deficiency and associated risk factors in the US Population (2011-2012). Cureus. (2018) 10:e2741. doi: 10.7759/cureus.2741

52. Holick MF. High prevalence of vitamin D inadequacy and implications for health. Mayo Clin Proc. (2006) 81:353-73. doi: 10.4065/81.3.353

53. Rostand SG. Ultraviolet light may contribute to geographic and racial blood pressure differences. Hypertension. (1997) 30:150-6. doi: 10.1161/01.HYP.30.2.150

54. Zittermann A, Schleithoff SS, Tenderich G, Berthold HK, Körfer $\mathrm{R}$, Stehle P. Low vitamin D status: A contributing factor in the pathogenesis of congestive heart failure? J Am Coll Cardiol. (2003) 41:105-12. doi: 10.1016/S0735-1097(02)02624-4

55. Bell C. Ultraviolet light may contribute to geographic and racial blood pressure differences. Hypertension. (1998) 31:719. doi: 10.1161/01.HYP.31.2.719

56. Karagiannis A, Tziomalos K, Mikhailidis DP, Semertzidis P, Kountana E, Kakafika AI, et al. Seasonal variation in the occurrence of stroke in Northern Greece: a 10 year study in 8204 patients. Neurol Res. (2010) 32:32631. doi: $10.1179 / 174313208 \times 331608$

57. Buell JS, Dawson-Hughes B, Scott TM, Weiner DE, Dallal GE, Qui WQ, et al. 25-Hydroxyvitamin D, dementia, and cerebrovascular pathology in elders receiving home services. Neurology. (2010) 74:18-26. doi: 10.1212/WNL.0b013e3181beecb7

58. Kent ST, McClure LA, Judd SE, Howard VJ, Crosson WL, Al-Hamdan MZ, et al. Short- and long-term sunlight radiation and stroke incidence. Ann Neurol. (2013) 73:32-7. doi: 10.1002/ana.23737

59. Poole KES, Loveridge N, Barker PJ, Halsall DJ, Rose C, Reeve J, et al. Reduced vitamin D in acute stroke. Stroke. (2006) 37:2435. doi: 10.1161/01.STR.0000195184.24297.c1

60. Sun Q, Pan A, Hu FB, Manson JE, Rexrode KM. 25-Hydroxyvitamin D levels and the risk of stroke: a prospective study and meta-analysis. Stroke. (2012) 43:1470-77. doi: 10.1161/STROKEAHA.111.636910

61. Pilz S, Dobnig H, Fischer JE, Wellnitz B, Seelhorst U, Boehm BO, et al. Low vitamin d levels predict stroke in patients referred to coronary angiography. Stroke. (2008) 39:2611-3. doi: 10.1161/STROKEAHA.107.513655

62. Leu Agelii M, Lehtinen-Jacks S, Zetterberg H, Sundh V, Björkelund C, Lissner L. Low vitamin D status in relation to cardiovascular disease and mortality in Swedish women - effect of extended follow-up. Nutr Metab Cardiovasc Dis. (2017) 27:1143-51. doi: 10.1016/j.numecd.2017.10.013

63. Li J, Lai H, Yang L, Zhu H, Chen S, Lai S. Age and gender differences in the association between serum 25-hydroxyvitamin $\mathrm{D}$ and stroke in the general US population: The National Health and Nutrition Examination Survey, 2001-2006. J Stroke Cerebrovasc Dis. (2017) 26:25108. doi: 10.1016/j.jstrokecerebrovasdis.2017.05.045

64. Kojima G, Bell C, Abbott RD, Launer L, Chen R, Motonaga H, et al. Low dietary vitamin D predicts 34-year incident stroke: the honolulu heart program. Stroke. (2012) 43:2163-7. doi: 10.1161/STROKEAHA.112.651752

65. Melamed ML, Michos ED, Post W, Astor B. 25-hydroxyvitamin D levels and the risk of mortality in the general population. Arch Intern Med. (2008) 168:1629-37. doi: 10.1001/archinte.168.15.1629

66. Wang L, Song Y, Manson JE, Pilz S, März W, Michaëlsson K, et al. Circulating 25-hydroxy-vitamin D and risk of cardiovascular disease: a meta-analysis of prospective studies. Circ Cardiovasc Qual Outcomes. (2012) 5:819-29. doi: 10.1161/CIRCOUTCOMES.112.967604
67. Michos ED, Reis JP, Post WS, Lutsey PL, Gottesman RF, Mosley TH, et al. 25Hydroxyvitamin D deficiency is associated with fatal stroke among whites but not blacks: the NHANES-III linked mortality files. Nutrition. (2012) 28:367-71. doi: 10.1016/j.nut.2011.10.015

68. Judd SE, Morgan CJ, Panwar B, Howard VJ, Wadley VG, Jenny NS, et al. Vitamin D deficiency and incident stroke risk in community-living black and white adults. Int J Stroke. (2016) 11:93-102. doi: 10.1177/1747493015607515

69. Schneider AL, Lutsey PL, Selvin E, Mosley TH, Sharrett AR, Carson KA, et al. Vitamin D, vitamin D binding protein gene polymorphisms, race and risk of incident stroke: the Atherosclerosis Risk in Communities (ARIC) study. Eur J Neurol. (2015) 22:1220-7. doi: 10.1111/ene.12731

70. Wei ZN, Kuang JG. Vitamin D deficiency in relation to the poor functional outcomes in nondiabetic patients with ischemic stroke. Biosci Rep. (2018) 38:BSR20171509. doi: 10.1042/BSR20171509

71. Drechsler C, Pilz S, Obermayer-Pietsch B, Verduijn M, Tomaschitz A, Krane $\mathrm{V}$, et al. Vitamin D deficiency is associated with sudden cardiac death, combined cardiovascular events, and mortality in haemodialysis patients. Eur Heart J. (2010) 31:2253-61. doi: 10.1093/eurheartj/ehq246

72. Lafi ZM, Irshaid YM, El-Khateeb M, Ajlouni KM, Hyassat D. Association of rs7041 and rs4588 polymorphisms of the vitamin D binding protein and the rs10741657 polymorphism of CYP2R1 with vitamin D status among Jordanian patients. Genet Test Mol Biomarkers. (2015) 19:62936. doi: $10.1089 / \mathrm{gtmb} .2015 .0058$

73. Kühn T, Kaaks R, Teucher B, Hirche F, Dierkes J, Weikert C, et al. Plasma 25-hydroxyvitamin $\mathrm{D}$ and its genetic determinants in relation to incident myocardial infarction and stroke in the European prospective investigation into cancer and nutrition (EPIC)-Germany study. PLoS One. (2013) 8:e69080. doi: 10.1371/journal.pone.0069080

74. Afzal S, Nordestgaard BG. Vitamin D, hypertension, and ischemic stroke in 116,655 individuals from the general population: a genetic study. Hypertension. (2017) 70:499507. doi: 10.1161/HYPERTENSIONAHA.117.09411

75. Narasimhan S, Balasubramanian P. Role of vitamin D in the outcome of ischemic stroke- a randomized controlled trial. J Clin Diagn Res. (2017) 11:CC06-10. doi: 10.7860/JCDR/2017/24299.9346

76. Gupta A, Prabhakar S, Modi M, Bhadada SK, Kalaivani M, Lal V, et al. Effect of Vitamin D and calcium supplementation on ischaemic stroke outcome: a randomised controlled open-label trial. Int J Clin Pract. (2016) 70:764-70. doi: 10.1111/ijcp. 12866

77. Manson JE, Cook NR, Lee I-M, Christen W, Bassuk SS, Mora S, et al. Vitamin D supplements and prevention of cancer and cardiovascular disease. $N$ Engl J Med. (2019) 380:33-44. doi: 10.1056/NEJMoa1809944

78. Raed A, Bhagatwala J, Zhu H, Pollock NK, Parikh SJ, Huang $\mathrm{Y}$, et al. Dose responses of vitamin $\mathrm{D}_{3}$ supplementation on arterial stiffness in overweight African Americans with vitamin D deficiency: a placebo controlled randomized trial. PLOS ONE. (2017) 12:e0188424. doi: 10.1371/journal.pone.0188424

79. Tarcin O, Yavuz DG, Ozben B, Telli A, Ogunc AV, Yuksel M, et al. Effect of vitamin D deficiency and replacement on endothelial function in asymptomatic subjects. J Clin Endocrinol Metab. (2009) 94:402330. doi: $10.1210 /$ jc. $2008-1212$

80. Witham MD, Dove FJ, Sugden JA, Doney AS, Struthers AD. The effect of vitamin D replacement on markers of vascular health in stroke patients a randomised controlled trial. Nutr Metab Cardiovasc Dis. (2012) 22:86470. doi: 10.1016/j.numecd.2010.11.001

81. Sugden JA, Davies JI, Witham MD, Morris AD, Struthers AD. Vitamin D improves endothelial function in patients with Type 2 diabetes mellitus and low vitamin D levels. Diabet Med. (2008) 25:320-5. doi: 10.1111/j.1464-5491.2007.02360.x

82. Aytaç MB, Deveci M, Bek K, Kayabey Ö, Ekinci Z. Effect of cholecalciferol on local arterial stiffness and endothelial dysfunction in children with chronic kidney disease. Pediatr Nephrol. (2016) 31:267-77. doi: 10.1007/s00467-015-3220-5

83. Gepner AD, Ramamurthy R, Krueger DC, Korcarz CE, Binkley N, Stein $\mathrm{JH}$. A prospective randomized controlled trial of the effects of vitamin D supplementation on cardiovascular disease risk. PLoS One. (2012) 7:e36617. doi: 10.1371/journal.pone.0036617 
84. Yiu Y-F, Yiu K-H, Siu C-W, Chan Y-H, Li S-W, Wong L-Y, et al. Randomized controlled trial of vitamin D supplement on endothelial function in patients with type 2 diabetes. Atherosclerosis. (2013) 227:1406. doi: 10.1016/j.atherosclerosis.2012.12.013

85. Chan Y-H, Lau K-K, Yiu K-H, Li S-W, Tam S, Lam T-H, et al. Vascular protective effects of statin-related increase in serum 25-hydroxyvitamin D among high-risk cardiac patients. J Cardiovasc Med (Hagerstown). (2015) 16:51-8. doi: 10.2459/JCM.0000000000000026

86. Bolland MJ, Grey A, Avenell A, Gamble GD, Reid IR. Calcium supplements with or without vitamin D and risk of cardiovascular events: reanalysis of the Women's Health Initiative limited access dataset and meta-analysis. BMJ. (2011) 342:d2040. doi: 10.1136/bmj.d2040

87. Shah SM, Carey IM, Harris T, DeWilde S, Cook DG. Calcium supplementation, cardiovascular disease and mortality in older women. Pharmacoepidemiol Drug Saf. (2010) 19:59-64. doi: 10.1002/pds.1859

88. Scragg R, Stewart AW, Waayer D, Lawes CMM, Toop L, Sluyter J, et al. Effect of monthly high-dose vitamin D supplementation on cardiovascular disease in the vitamin $\mathrm{D}$ assessment study : a randomized clinical trial. JAMA Cardiol. (2017) 2:608-16. doi: 10.1001/jamacardio.2017.0175

89. de Abajo FJ, Rodríguez-Martín S, Rodríguez-Miguel A, Gil MJ. Risk of ischemic stroke associated with calcium supplements with or without vitamin D: a nested case-control study. J Am Heart Assoc. (2017) 6:e005795. doi: 10.1161/JAHA.117.005795

90. Sluyter JD, Camargo CA, Stewart AW, Waayer D, Lawes CMM, Toop L, et al. Effect of monthly, high-dose, long-term vitamin D supplementation on central blood pressure parameters: a randomized controlled trial substudy. J Am Heart Assoc. (2017) 6:e006802. doi: 10.1161/JAHA.117. 006802

91. Stojanović M, Radenković M. Vitamin D versus placebo in improvement of endothelial dysfunction: a meta-analysis of randomized clinical trials. Cardiovasc Ther. (2015) 33:145-54. doi: 10.1111/1755-5922.12122

92. Mazidi M, Karimi E, Rezaie P, Vatanparast H. The impact of vitamin D supplement intake on vascular endothelial function; a systematic review and meta-analysis of randomized controlled trials. Food Nutr Res. (2017) 61:1273574. doi: 10.1080/16546628.2016.1273574

93. Beveridge LA, Khan F, Struthers AD, Armitage J, Barchetta I, Bressendorff I, et al. Effect of vitamin D supplementation on markers of vascular function: a systematic review and individual participant metaanalysis. J Am Heart Assoc. (2018) 7:e008273. doi: 10.1161/JAHA.117. 008273

94. Tabrizi R, Vakili S, Lankarani KB, Akbari M, Jamilian M, Mahdizadeh Z, et al. The effects of vitamin D supplementation on markers related to endothelial function among patients with metabolic syndrome and related disorders: a systematic review and meta-analysis of clinical trials. Horm Metab Res (2018) 50:587-96. doi: 10.1055/a-0651-4842

95. Bonakdaran S, Varasteh A-R. Correlation between serum 25 hydroxy vitamin D3 and laboratory risk markers of cardiovascular diseases in type 2 diabetic patients. Saudi Med J. (2009) 30:509-14.

96. Grant WB. Re: "Vitamin D deficiency and cardiovascular events in patients with coronary heart disease: data from the heart and soul study". Am J Epidemiol. (2014) 180:757-8. doi: 10.1093/aje/kwu215

97. Annweiler C, Le Gall D, Fantino B, Beauchet O, Tucker KL Buell JS. 25-hydroxyvitamin D, dementia, and cerebrovascular pathology in elders receiving home services. Neurology. (2010) 75:95. doi: 10.1212/WNL.0b013e3181e00ddb

98. Mihaila S. Vitamin D deficiency is associated with sudden cardiac death, combined cardiovascular events, and mortality in haemodialysis patients. Maedica (Buchar). (2010) 5:228.

99. Lowe DW, Hollis BW, Wagner CL, Bass T, Kaufman DA, Horgan $\mathrm{MJ}$, et al. Vitamin D insufficiency in neonatal hypoxic-ischemic encephalopathy. Pediatr Res. (2017) 82:55-62. doi: 10.1038/pr.2 017.13

100. Wajda J, Swiat M, Owczarek AJ, Brzozowska A, Olszanecka-Glinianowicz M, Chudek J. Severity of vitamin D deficiency predicts mortality in ischemic stroke patients. Dis Markers. (2019) 2019:3652894. doi: 10.1155/2019/365 2894

101. Hu W, Liu D, Li Q, Wang L, Tang Q, Wang G. Decreasing serum 25-hydroxyvitamin D levels and risk of early neurological deterioration in patients with ischemic stroke. Brain Behav. (2019) 9:e01227. doi: 10.1002/brb3.1227

102. Daubail B, Jacquin A, Guilland JC, Hervieu M, Osseby GV, Rouaud O, et al. Serum 25-hydroxyvitamin D predicts severity and prognosis in stroke patients. Eur J Neurol. (2013) 20:57-61. doi: 10.1111/j.1468-1331.2012.0 3758.x

Conflict of Interest: The authors declare that the research was conducted in the absence of any commercial or financial relationships that could be construed as a potential conflict of interest.

Copyright (c) 2020 Yarlagadda, Ma and Doré. This is an open-access article distributed under the terms of the Creative Commons Attribution License (CC BY).

The use, distribution or reproduction in other forums is permitted, provided the original author(s) and the copyright owner(s) are credited and that the original publication in this journal is cited, in accordance with accepted academic practice. No use, distribution or reproduction is permitted which does not comply with these terms. 